Chapman University

Chapman University Digital Commons

Food Science (MS) Theses

Dissertations and Theses

Spring 5-28-2019

\title{
Use of PCR Cloning Combined with DNA Barcoding to Identify Fish in a Mixed-Species Product
}

Anthony Silva

Chapman University, silva130@mail.chapman.edu

Follow this and additional works at: https://digitalcommons.chapman.edu/food_science_theses

\section{Recommended Citation}

Silva, A. (2019). Use of PCR cloning combined with DNA barcoding to identify fish in a mixed-species product. Master's thesis, Chapman University. https://doi.org/10.36837/chapman.000065

This Thesis is brought to you for free and open access by the Dissertations and Theses at Chapman University Digital Commons. It has been accepted for inclusion in Food Science (MS) Theses by an authorized administrator of Chapman University Digital Commons. For more information, please contact laughtin@chapman.edu. 


\title{
Use of PCR cloning combined with DNA barcoding to identify fish in a mixed- species product
}

\author{
A Thesis by \\ Anthony J. Silva \\ Chapman University \\ Orange, CA \\ Schmid College of Science and Technology \\ Master of Science in Food Science \\ May 2019 \\ Committee in charge: \\ Rosalee Hellberg, Ph.D., Advisor \\ Michael Kawalek, Ph.D. \\ Anuradha Prakash, Ph.D.
}

Submitted in partial fulfillment of the requirements for the degree of 
The thesis of Anthony J. Silva is approved.

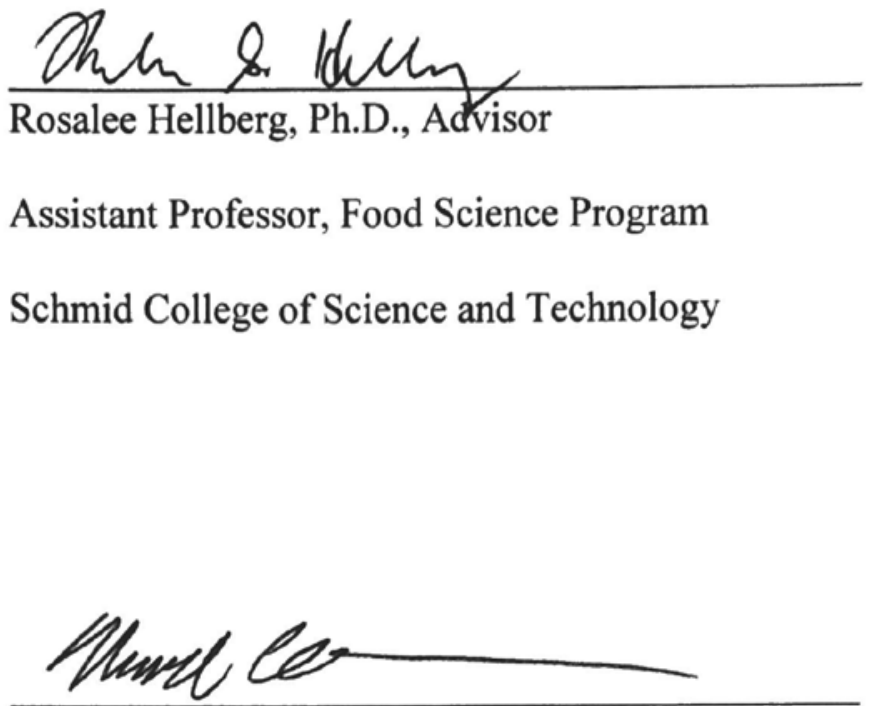

Michael Kawalek, Ph.D.

Microbiologist

U.S. Food and Drug Administration

$\frac{\text { Ahundhe Pretuenh }}{\text { Anuradha Prakash, Ph.D. }}$

Professor, Director, Food Science Program

Schmid College of Science and Technology 
Use of PCR cloning combined with DNA barcoding to identify fish in a mixedspecies product

Copyright () 2019

by Anthony J. Silva 


\section{ACKNOWLEDGMENTS}

The author wishes to thank Dr. Rosalee Hellberg for being an approachable, helpful, and knowledgeable Thesis advisor. Dr. Michael Kawalek for his help and execution of the project. Dr. Anuradha Prakash for her advice and taking the time to be on my thesis committee. Thank you to my friends and fellow classmates: Brian Nyakundi, Maria Khalil, Priscilla George, Rashi Bhatnagar. Special thanks to Rachel Isaacs for assisting me with lab techniques and being a supportive friend. I would like to acknowledge the faculty of Schmid College of Science and Technology at Chapman University. 


\section{ABSTRACT \\ Use of PCR cloning combined with DNA barcoding to identify fish in a mixed- species product}

by Anthony J. Silva

DNA barcoding is a valuable tool for fish species identification by food regulators, however, it does not perform well when multiple species are present within the same food product. PCR cloning has high potential to be used in combination with DNA barcoding to overcome this challenge. The objective of this study was to examine the use of PCR cloning combined with DNA barcoding to identify fish in a mixed-species product that cannot be identified with standard DNA barcoding. A total of 15 fish ball mixtures were prepared with known amounts of Nile tilapia (Oreochromis niloticus), Pacific cod (Gadus macrocephalus), and walleye pollock (Gadus chalcogrammus). The fish balls underwent DNA extraction in triplicate, followed by DNA barcoding across the full barcode (655 bp) and SH-E mini-barcode (226 bp) of the cytochrome c oxidase subunit 1 (CO1) region. Samples that did not pass sequencing according to regulatory standards were further analyzed with PCR cloning. Full barcoding enabled identification of at least one species in $80 \%$ of the fish ball mixtures compared to $51 \%$ for minibarcoding. The results of PCR cloning with samples that did not pass DNA barcoding showed identification success rates of $61 \%$ for clones (54 of 90) that underwent full barcoding and 51\% for clones (111 of 220) that underwent mini-barcoding. All fish balls made of just one species tested positive for that species (i.e., tilapia, cod, or pollock).. The combination of standard full barcoding and PCR cloning enabled identification of Nile tilapia in all 12 mixed-species fish balls and Pacific cod in 6 of 12 (50\%) of mixed- 
species fish balls. In comparison, the combination of standard mini-barcoding and PCR cloning enabled identification of Nile tilapia in all 12 mixed-species fish balls and Pacific cod in 9 of 12 (75\%) of mixed-species fish balls. Overall, the results of this study show that PCR cloning may be an effective method to identify certain fish in mixed-species products when standard DNA barcoding fails. However, additional research is needed to understand the limitations associated with primer bias. 


\section{Table of Contents}

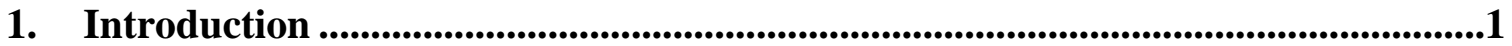

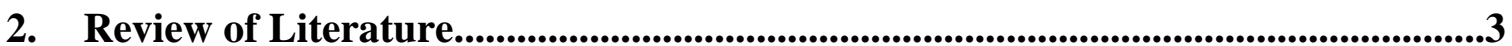

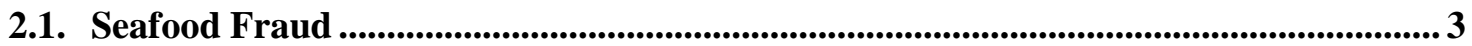

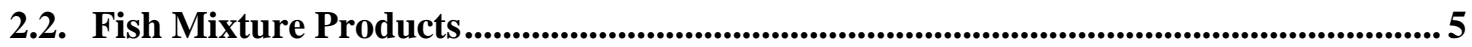

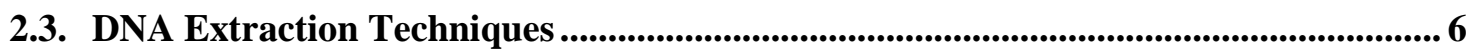

2.4. DNA Sequencing-based Methods for Identifying Fish Species..................................6

2.4.1. DNA Barcoding ............................................................................................................. 6

2.4.2. Next Generation Sequencing...................................................................................... 8

2.4.3. PCR cloning analysis ..................................................................................................... 11

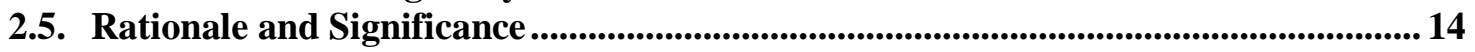

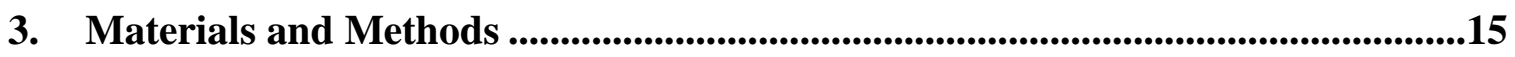

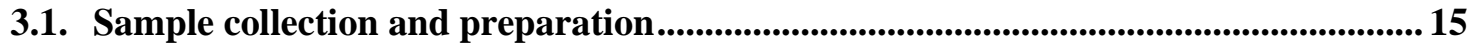

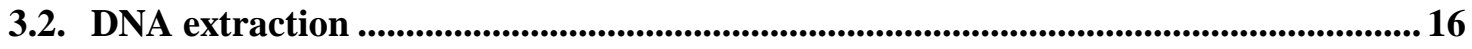

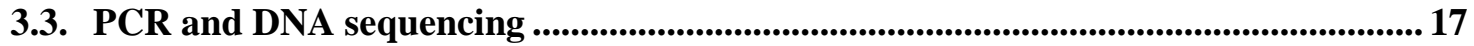

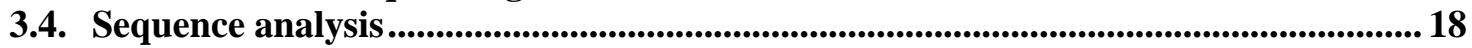

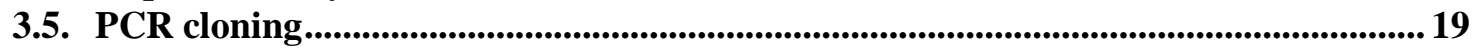

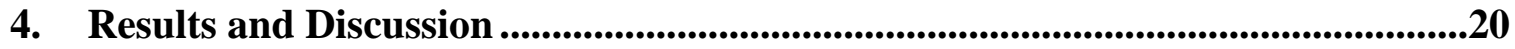

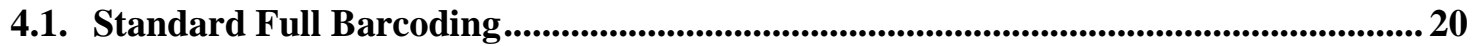

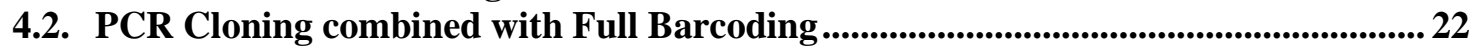

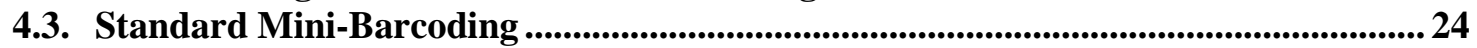

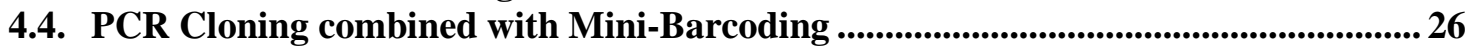

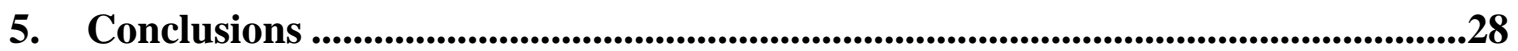

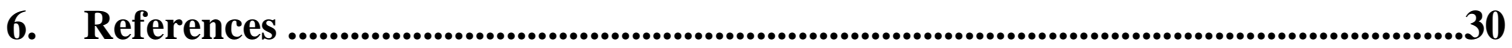




\section{LIST OF TABLES}

Table 1: Comparison of next generation sequencing techniques and Sanger sequencing; Adapted from Liu and others (2012)

Table 2: Next generation sequencing of fish products...............................................11

Table 3: PCR cloning studies for species identification in a variety of samples

Table 4. Sequencing results for fish ball samples tested in triplicate with full and miniDNA barcoding. Samples contained varying amounts of Nile tilapia ( $O$. niloticus), Pacific cod (G. macrocephalus), and walleye pollock ( $T$. chalcogramma).

Table 5. Sequencing results for fish ball subsamples that underwent PCR cloning and full DNA barcoding after failing standard full barcoding. Ten clones were sequenced for each PCR product that failed standard barcoding.

Table 6. Sequencing results for fish ball samples that underwent PCR cloning and minibarcoding after failing standard mini-barcoding. Ten clones were sequenced for each PCR product that failed standard barcoding. .28 


\section{LIST OF FIGURES}

Figure 1: Comparison of (a) DNA Barcoding and (b) PCR cloning for analysis of species

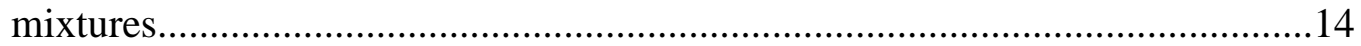




\section{LIST OF ABBREVIATIONS}

BOLD- Barcode of Life Database

CO1- cytochrome $c$ oxidase subunit 1 gene

PCR- polymerase chain reaction

FDA - U.S. Food and Drug Administration

IUCN- International Union for the Conservation of Nature 


\section{Introduction}

Food fraud, including species substitution and mislabeling, is a concern within the seafood industry. The United States is a major importer of fish and fish-based products, with annual imports valued at US \$20.5 billion in 2016 (FAO 2018). The vulnerability of these products to food fraud is high due to fluctuations in product quality, supply, and demand. Species substitution and mislabeling is largely motivated through the economic gain that results from substitution of an inexpensive fish for a premium fish (Khaksar and others 2015). However, species substitution can have serious consequences, including exposure to toxins and allergens, infringement of religious practices, and financial loss (Armani and others 2015).

Some seafood products, such as fish balls, fish cakes and surimi, are made with a range of fish species and can readily be adulterated due to the lack of morphological identifiers (Carvalho and others 2017a; Galal-Khallaf and others 2016). For example, a previous study involving 22 processed cod products (including fish cakes) purchased in Brazil found that $41 \%$ of samples were mislabeled and $31 \%$ of samples consisted of two or more species (Carvalho and others 2017b). Mixed fish products, such as fish cakes and fish balls, are consumed worldwide in regions such as Asia, Brazil, and Scandinavia. A wide variety of species are commonly used for production of mixed fish products, including walleye pollock (Gadus chalcogrammus), Pacific whiting (Merluccius productus), tilapia (Oreochromis spp.), and Pacific cod (Gadus microcephalus) (Carvalho and others 2017b; Morrissey and Guenneugues 2000; Ninan and others 2010).

DNA barcoding is typically used by the U.S. Food and Drug Administration (FDA) to identify fish species in food for regulatory purposes (Handy and others 
2011b). In DNA full-barcoding, a 650 base-pair (bp) region of the cytochrome $c$ oxidase subunit 1 (CO1) gene is sequenced and compared to reference sequences to enable species identification. While full barcoding has been shown to work well with raw or minimally processed single-species products, challenges have arisen in the identification of more processed products. One means of addressing these challenges has been the development of DNA mini-barcodes that target shorter regions ( 100300 bp) of CO1 (Shokralla and others 2015). DNA mini-barcodes have been found to perform well for species identification in a variety of processed products (Shokralla and others 2015; Pollack and others 2018). However, both full and mini DNA barcoding utilize Sanger sequencing and, therefore, often fail to identify species when two or more species are mixed in the same sample (Carvalho and others 2017b). This is because the presence of multiple species in the same sample can lead to the generation of multiple, overlapping peaks on the resulting sequencing chromatogram, making it unreadable.

PCR cloning has previously been used in combination with DNA barcoding for species identification in mixed-species fish products (Galal-Khallaf and others 2016). This technique involves the use of an E. coli-based cloning vector to isolate DNA amplicons from different species in the same sample (Galal-Khallaf and others 2016; Rondon and others 2000). The resulting amplicons can then be sequenced separately and identified using DNA barcoding techniques. PCR cloning in combination with minibarcoding (127 bp) of the CO1 gene was previously evaluated for its ability to identify species in 100\% (29 out of 29) commercial surimi products from China, Singapore, and India (Galal-Khallaf and others 2016). This method enabled identification of an average 
of 2.3, 1.6, and 1.0 species per product from Singapore, China, and India, respectively. Common species identified in this study included Sutchi catfish (Pangasianodon hypophthalmus), yellowbelly threadfin bream (Nemipterus bathybius), and fringescale sardinella (Sardinella fimbriata). PCR cloning has been used previously for the identification of species in other applications involving mixed samples, such as detection of animal species in pet food (Teletchea and others 2005; Donne-Gousse and others 2005), identification of plant species in honey (Bruni and others 2015), and analysis of fish species in the fecal material of predators (Murray and others 2011; Deagle and others 2005).

Although various DNA barcoding techniques have been established for species identification, no definitive research has been done on the ability of PCR cloning combined with DNA barcoding to identify specific fish in a mixed-species sample with known amounts of each species. Therefore, the objective of this study was to examine the use of PCR cloning combined with DNA barcoding to identify fish in a mixed-species product (i.e., fish balls) that cannot be identified with standard DNA barcoding. This method was tested using both mini-barcoding and full barcoding in order to determine which barcoding technique is most appropriate for this application.

\section{Review of Literature}

\subsection{Seafood Fraud}

Globally, billions of people depend on fish as a source of protein, with over one billion people eating fish daily (WHO 2017). However, seafood fraud is a major concern because species with different market values can be similar in appearance. Economic gain is the primary motivation to mislabel fish products and the differences in value have 
enhanced the exposure of fish to fraudulent activity (Carvalho and others 2017a). Species substitution is a major economic fraud concern in the seafood industry, in which substitution of an inexpensive fish for a premium labeled fish is impacting the global fish trade market (NOC 2016). Numerous studies have determined mislabeling of various fish species, such as Atlantic salmon (Salmo salar) being mislabeled as Pacific salmon (Oncorhynchus sp.) (Cline 2012), tra fish (Pangasius hypophthalamus) being sold as a highly valuable Nile perch (Lates niloticus) (Galal-Khallaf and others 2014), and Pacific cod (Gadus macrocephalus) labeled as Atlantic cod (Gadus morhua) (Di Pinto and others 2013).

Another major concern for food fraud is multi-species products, such as fish balls or cakes, due to high processing and the inability to morphologically identify the various fish species. Recent reports have identified mislabeling of surimi-based products, including the substitution of various undeclared species for walleye pollock (GalalKhallaf and others 2016). Mislabeling of fish mixture products is problematic from the standpoint of food allergens and health concerns. Specific allergens to seafood, such as fish and crab, can put consumers at high risk if a specific product is mislabeled (Fox and others 2018).

Concerns with overfishing of specific fish species, such as walleye pollock and Atlantic cod, has led to various conservation efforts (Lago and others 2013; Morrissey and Guenneugues 2000). The use of alternate fish species, including threadfin bream and Pacific cod, has been the most efficient and effective way for preventing over harvesting and concerns with species endangerment. In general, the International Union for Conservation of Nature (IUCN) focuses on protecting declining species from extinction 
along with tracking species. The IUCN has classified the Atlantic cod as Vulnerable on the Red List of Threatened Species (Nature 2017). With this, fisheries have captured alternative species, such as bass and haddock, for use in processed fish products. Regulation of processed fish mixture products, including fish balls and fish cakes, is a major concern due to the inability to morphologically identify species in a given sample (Carvalho and others 2017b). Several DNA-based methods, such as DNA barcoding and real-time PCR, can be used to identify species. However, there are some limitations to these methods, as discussed in subsequent sections.

\subsection{Fish Mixture Products}

Fish mixtures, which are defined as a product consisting of two or more species of fish, are found in various forms, including fish cakes, balls, or sticks. Over 22,000 tons of these various mixtures are produced annually and distributed within the global market (Tee and Siow 2014). Fish balls are commonly consumed in Scandinavia and various Southeast Asian countries, including Singapore, Malaysia, and Indonesia. Fish balls consist of four basic ingredients: fish (40\%), starch (50\%), salt (2\%), and ice water (8\%), which are shaped into a ball and typically boiled (Morrissey and Guenneugues 2000). The most widely used species for fish mixture production is the walleye pollock (Carvalho and others 2017b). The primary method of producing fish balls is through grinding of the fish meat and the addition of salt, starch, and water (Boran and Kose 2007). Production of fish balls has been altered due to the overfishing of walleye pollock, and therefore fish balls are being made using other fish, including threadfin bream, tilapia, and pacific whiting (Morrissey and Guenneugues 2000). As well, various cod 
species, including Atlantic and Pacific cod, have shown catastrophic declines in overall stock volumes (Lago and others 2013).

\subsection{DNA Extraction Techniques}

The traditional protocol for DNA extraction from fish tissues uses phenol and chloroform to denature and extract DNA (Cawthorn and others 2011). A major concern about this method is that chloroform is a carcinogen. Other methods that have been used to extract DNA from fish species include the urea-SDS-proteinase K method and Rapid MT. These alternate processes are not favorable due to the time, use of various reagents, and lack of separation and DNA isolation (Cawthorn and others 2011).

Commercial DNA extraction kits are available for use with fish products, including the DNeasy Blood \& Tissue kit (Handy and others 2011b). This kit allows for multi-sample processing with specific buffers that lyse cells and it uses a silica-based column to bind DNA. The DNeasy Blood \& Tissue kit was found to have $100 \%$ sequencing success in a study comparing it to Extract-N-AMP Tissue Kit (98\%) and Mag-96 DNA multi-Sample kit (99\%) (Hellberg and others 2014). The DNeasy kit has been extensively used for fish species identification, including walleye pollock, Pacific

cod, and Nile tilapia (Pollack and others 2018; Hellberg and others 2014). Furthermore, the FDA-validated DNA extraction method for fish species identification utilizes the DNeasy Blood \& Tissue kit (Handy and others 2011b).

\subsection{DNA Sequencing-based Methods for Identifying Fish Species}

\subsubsection{DNA Barcoding}

DNA barcoding is a sequencing-based technique that has been used to identify species in fish products around the world, including South America, Europe, Australia, 
and the United States (Carvalho and others 2017b; Angel Pardo and others 2018; Pollack and others 2018; Galal-Khallaf and others 2016). Most studies have used full DNA barcoding targeting a 650-bp fragment of the mitochondrial gene coding for CO1. The segments on either end of the CO1 region are relatively well-conserved, allowing for universal primers to be used for sequencing and identification of a broad range of species (Ivanova and others 2007). After DNA extraction, the sample is amplified through PCR and the CO1 sequence is analyzed and compared to the Barcode of Life Data System (BOLD), which enables species identification by comparison to sequences with known species. The gold standard of sequencing has been Sanger Sequencing, in which 4 dideoxynucleotides triphosphates (ddNTPs) (i.e., adenine, guanine, cytosine, and thymine) are fluorescently tagged and read as they pass through the detector (Shokralla and others 2014).

While DNA barcoding of the CO1 gene is a successful technique for fish species identification, full barcoding has become a challenge in heavily processed foods due to DNA degradation (Shokralla and others 2015). Shokralla and others (2015) developed a DNA mini-barcoding system to identify fish species in processed products by sequencing shorter DNA fragments of 100-300 bp. Overall, the mini barcoding system showed high species identification success (93\%) for the six mini-barcode primers tested. Among the mini-barcode primers developed by Shokralla and others (2015), the SH-E primer was found to be the most effective, with an $88.6 \%$ success rate (Shokralla and others 2015). A recent study by Pollack and others (2018) assessed the impact of various cooking techniques on fish species identification using the mini SH-E primer and reported a 92\% overall success rate. 
Another challenge that occurs with DNA barcoding is the reliable identification of species in mixed products. DNA barcoding is unable to distinguish multiple species in a given mixed sample due to multiple PCR amplicons of different species that will produce a multi-peak chromatogram. Additional research is needed to develop and apply techniques, such as PCR cloning or next-generation sequencing, that enable simultaneous identification of a wide range of fish species in a mixed-species product.

\subsubsection{Next Generation Sequencing}

Next generation sequencing (NGS) is a rapid, high cost biotechnology-based identification technique that was introduced in 2005 (Thomas and others 2012). Specific NGS techniques used today for fish species identification include pyrosequencing, Ion Torrent, and Illumina platforms (De Battisti and others 2014; Carvalho and others 2017b; Park and others 2012). 
Table 1: Comparison of next generation sequencing techniques and Sanger sequencing; Adapted from Liu and others (2012)

\begin{tabular}{|c|c|c|c|c|c|c|}
\hline Method & $\begin{array}{l}\text { Principle } \\
\text { Technique }\end{array}$ & $\begin{array}{l}\text { Read length } \\
\text { (bp) }\end{array}$ & $\begin{array}{l}\text { Accuracy } \\
\text { of a } \\
\text { single } \\
\text { read (\%) }\end{array}$ & $\begin{array}{l}\text { Reads per } \\
\text { run }\end{array}$ & $\begin{array}{l}\text { Time per run } \\
\text { (hours) }\end{array}$ & $\begin{array}{l}\text { Cost } \\
\text { per } 1 \\
\text { millio } \\
n \\
\text { bases } \\
\end{array}$ \\
\hline $\begin{array}{l}\text { Ion Torrent } \\
\text { Sequencing }\end{array}$ & $\begin{array}{l}\text { Ion Chip that } \\
\text { isolates } \\
\text { hydrogen ions } \\
\text { released from } \\
\text { DNA }\end{array}$ & Up to 600 & 98 & $\begin{array}{l}\text { Up to } 80 \\
\text { million }\end{array}$ & 2 & $\$ 10.00$ \\
\hline $\begin{array}{l}\text { Pyrosequen } \\
\text { cing }\end{array}$ & $\begin{array}{l}\text { Detects } \\
\text { pyrophosphate } \\
\text { s released } \\
\text { correlated to } \\
\text { base pairs }\end{array}$ & 700 & 99.9 & 1 million & 24 & $\$ 0.13$ \\
\hline Illumina & $\begin{array}{l}\text { Sequencing of } \\
\text { immobilized } \\
\text { DNA } \\
\text { fragments }\end{array}$ & $\begin{array}{l}\text { Miseq: 50-600 } \\
\text { Hiseq: 50-500 }\end{array}$ & 99.3 & $\begin{array}{l}\text { Miseq: 1-25 } \\
\text { million } \\
\text { Hiseq: } 300 \\
\text { million-2 } \\
\text { billion }\end{array}$ & $\begin{array}{l}\text { 24-264, } \\
\text { dependent on } \\
\text { sequence type }\end{array}$ & $\begin{array}{l}\$ 0.05 \\
\text { to } \\
\$ 0.15\end{array}$ \\
\hline $\begin{array}{l}\text { Sanger } \\
\text { Sequencing }\end{array}$ & $\begin{array}{l}\text { Sequencing } \\
\text { using chain- } \\
\text { terminating } \\
\text { nucleotides }\end{array}$ & $400-900$ & 99.9 & $\begin{array}{l}1,000- \\
10,000\end{array}$ & $0.2-3$ & $\$ 2,400$ \\
\hline
\end{tabular}

Pyrosequencing is a method that relies on detection of light based on the release of pyrophosphates from DNA, emitting specific peaks correlated to specific base pairs (De Battisti and others 2014). De Battisti and others (2014) assessed whole and processed fish samples using pyrosequencing, in which 20 out of 25 species were identified to the genus and species level, including Northern rock sole (Lepidopsetta polyxystra) and European anchovy (Engraulis encrasicolus). On the other hand, Ion Torrent sequencing includes the detection of hydrogen ions released from DNA during DNA polymerization using a semiconductor chip. This technique is desired due to no nucleotides or optics necessary compared to other NGS techniques (Giusti and others 2017). Carvalho and others (2017b) used next generation sequences with Ion torrent to examine mislabeling of 
cod species in Brazilian fish mixture products, including fish cakes, cooked meals, and cod cakes (Table 2). The authors reported mislabeling in 4 of the 22 products, with 23\% of the products containing more than one species. Similarly, Giusti and others (2017) reported mislabeling in over 37\% of fish-based products in Spain, Germany, France, and China using the Ion Torrent analyzer.

The Illumina NGS platform uses a technique that immobilizes DNA fragments and carries out PCR amplification on the surface of a glass chip (Park and others 2012). During Illumina sequencing, DNA fragments form a library and are loaded into a flow cell apparatus, in which each fragment is then amplified to a clonal cluster through bridge amplification (Kappel and others 2017). Sequencing reagents are added and quantified using a HiSeq200 instrument, which consists of 16 channels, each channel consisting of hundreds of millions of DNA reads (Thomas and others 2012). These reads are aligned to a reference sequence that is compared to the newly sequenced reads. Kappel and others (2017) used the Illumina platform to test nine known tuna fish mixtures ranging from single species to three species per mixture with the cytb marker segments BDR (131 bp) and BMID (126 bp). The results revealed a considerable overrepresentation of skipjack tuna compared to the Thunnus species. As well, BDR had a higher average read number compared to BMID, respectively 372,363 bp and 359,103 bp per sample. Mixtures with as low as $1 \%$ tissue of a specific species were identified, yet quantification of ratios of specific fish was inaccurate. Similarly, Park and others (2012) successfully identified 39 species, including Pacific bluefin tuna (Thunnus orientalis) and walleye pollock (Theregra chalcogramma), from six fish cake samples using Illumina NGS. 
A major concern with NGS techniques is the large and complex data set generated that requires extensive training and software knowledge for analysis. As well, NGS is high-cost technique that involves expensive equipment and reagents for preparation, sequencing, and analysis.

Table 2: Next generation sequencing of fish products

\begin{tabular}{|c|c|c|}
\hline Product and Method & Key Result & References \\
\hline $\begin{array}{l}\text { Processed Cod products (frozen } \\
\text { cakes, cod pieces, vacuum } \\
\text { packaged meals), Ion torrent } \\
\text { Personal Genome Machine }\end{array}$ & $\begin{array}{l}\text { Mislabeling of } 41 \% \text { of fish cod } \\
\text { products, including substitution } \\
\text { with haddock and whiting }\end{array}$ & $\begin{array}{l}\text { (Carvalho and } \\
\text { others 2017b) }\end{array}$ \\
\hline $\begin{array}{l}\text { Mixed Tuna Samples, Illumina } \\
\text { miseq }\end{array}$ & $\begin{array}{l}\text { Species authentication of fish } \\
\text { mixtures is feasible with an } \\
\text { Illumina MiSeq NGS approach } \\
\text { targeting two short fragments of } \\
\text { the mitochondrial cytb gene }\end{array}$ & $\begin{array}{l}\text { (Kappel and } \\
\text { others 2017) }\end{array}$ \\
\hline $\begin{array}{l}\text { Fish Cake, GS Junior Titanium } \\
\text { Sequencing machine }\end{array}$ & Identified 39 of 44 fish species & $\begin{array}{l}\text { (Park and } \\
\text { others 2012) }\end{array}$ \\
\hline $\begin{array}{l}\text { Surimi, Ion torrent Personal } \\
\text { Genome Machine }\end{array}$ & $\begin{array}{l}37.5 \% \text { of surimi products were } \\
\text { mislabeled in non-EU countries } \\
\text { including Denmark and Croatia }\end{array}$ & $\begin{array}{l}\text { (Giusti and } \\
\text { others 2017) }\end{array}$ \\
\hline
\end{tabular}

\subsubsection{PCR cloning analysis}

PCR cloning has been widely used for genetic analysis of environmental samples of macroinvertebrates, yet has recently been assessed for species identification of samples containing multiple species of fish (Thomas and others 2012). PCR cloning includes certain additional steps compared to standard DNA barcoding, including PCR purification and vector cloning (Figure 1). Sample preparation is the first step, in which DNA extraction is conducted, followed by PCR amplification of either the mini or full barcode. The PCR amplicons then undergo vector-based cloning and are transformed into 
E. coli competent cells (Qiagen 2015). Plasmid purification is then conducted to purify DNA and isolate the PCR insert for DNA barcoding. Vector-based cloning systems for species identification have effectively identified various plant and animal species (Table 3). Table 3 provides examples of studies that used cloning techniques for species identification in plant and animal-based products.

Table 3: PCR cloning studies for species identification in a variety of samples

\begin{tabular}{|c|c|c|c|}
\hline Product & Method & Key Results & References \\
\hline Honey & $\begin{array}{l}\text { pGEM-T Easy } \\
\text { Vector System }\end{array}$ & $\begin{array}{l}\text { Identified } 315 \text { taxa within } 4 \\
\text { species of honey tested }\end{array}$ & $\begin{array}{l}\text { (Bruni and } \\
\text { others 2015) }\end{array}$ \\
\hline $\begin{array}{l}\text { Canned Pet } \\
\text { Food }\end{array}$ & $\begin{array}{l}\text { Ins T/A clone }{ }^{\mathrm{TM}} \\
\text { Polymerase } \\
\text { chain reaction } \\
\text { (PCR) Product } \\
\text { Cloning Kit }\end{array}$ & $\begin{array}{l}\text { A mix of five species sequences } \\
\text { was observed: seven clones of } \\
\text { beef (Bos taurus), four clones of } \\
\text { pig (Sus scrofa), five clones of } \\
\text { duck (Cairina moschata), seven } \\
\text { clones of chicken (Gallus } \\
\text { gallus), and seven clones of sea } \\
\text { trout (Salmo trutta). }\end{array}$ & $\begin{array}{l}\text { (Donne- } \\
\text { Gousse and } \\
\text { others 2005) }\end{array}$ \\
\hline Fecal Matter & $\begin{array}{l}\text { pGEMH-T } \\
\text { vectors }\end{array}$ & $\begin{array}{l}\text { A total of nine fish species were } \\
\text { identified from } 129 \text { sequences, } \\
\text { in } 22 \text { of the } 47 \text { samples }\end{array}$ & $\begin{array}{l}\text { (Murray and } \\
\text { others 2011) }\end{array}$ \\
\hline $\begin{array}{l}\text { Archeological } \\
\text { Mammoth }\end{array}$ & $\begin{array}{l}\text { Ins T/A clone }{ }^{\mathrm{TM}} \\
\text { Polymerase } \\
\text { chain reaction } \\
\text { (PCR) Product } \\
\text { Cloning Kit }\end{array}$ & $\begin{array}{l}\text { Identified seven families and } 6 \\
\text { plant orders }\end{array}$ & $\begin{array}{l}\text { (Giusti and } \\
\text { others 2017; } \\
\text { van Geel and } \\
\text { others 2011) }\end{array}$ \\
\hline Surimi & $\begin{array}{l}\text { Ins T/A clone }{ }^{\mathrm{TM}} \\
\text { PCR cloning Kit }\end{array}$ & $\begin{array}{l}\text { Identified } 10 \text { different fish } \\
\text { species in } 29 \text { surimi-based } \\
\text { samples }\end{array}$ & $\begin{array}{l}\text { (Galal-Khallaf } \\
\text { and others } \\
\text { 2016) }\end{array}$ \\
\hline
\end{tabular}

Interestingly, a surimi-based study conducted by Galal-Khallaf and others (2016) showed an effective thymine/adenine cloning kit that was successful (65\%) in identifying multiple fish in 29 surimi samples. Galal-Khallaf and others (2016) successfully 
amplified genomic DNA of surimi and transformed cells using Luria Broth with Ampicillin, X-Gal (20 mg/ml) containing 200 mg/ml IPTG antibiotic-based agar plates. Positive transformants changed color from yellow to white due to the coding sequence of the B-actin gene being disrupted by the insert. In contrast, the clones without inserts turned blue because of the activity of the intact B-actin gene (Galal-Khallaf and others 2016). The positive transformants underwent restriction enzyme digest with BamH1 and XbaI to analyze specific cloned vectors on agarose gels and the species on each individual plasmid clone was identified through DNA sequencing. In comparison, Donne Gouse and others (2005) analyzed the 380 bp cytochrome $b$ gene portion in DNA extracted from canned pet food and sequenced over 30 clones identifying various species of beef, pig, duck, and fish. Over 100 clones for five different honey species were DNA sequenced using $r b c L$ and trnH-psbA genomic regions by metagenomics-based cloning techniques in honey (Bruni and others 2015). Overall, PCR cloning has been an effective technique for species identification in mixed-species samples and has the potential to enhance detection of food fraud and mislabeling within mixture-based products. 
a) DNA barcoding

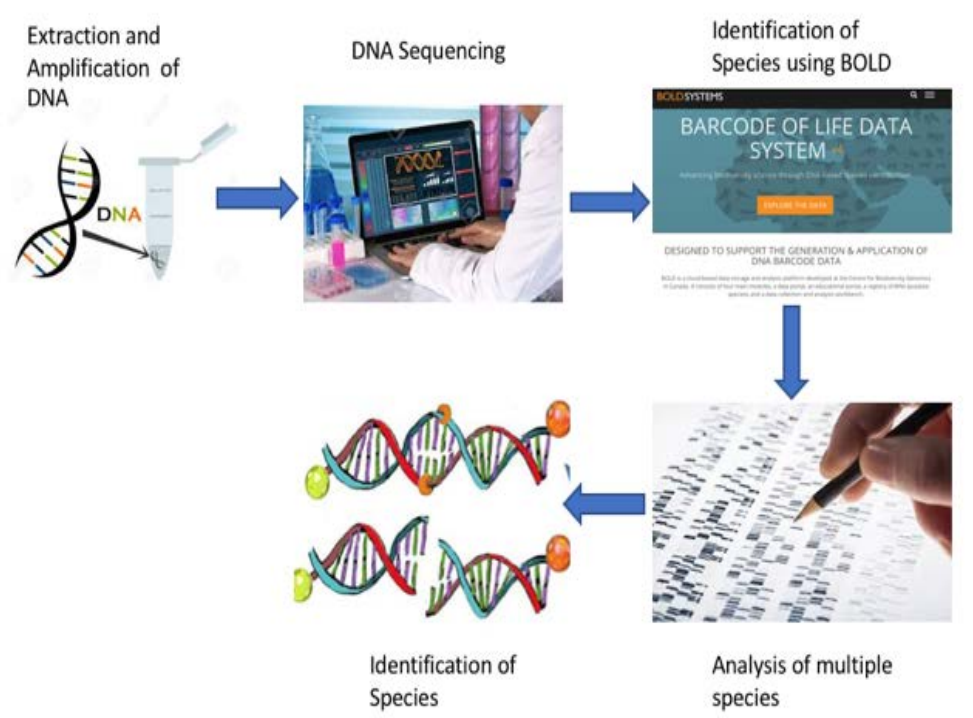

b) PCR Cloning

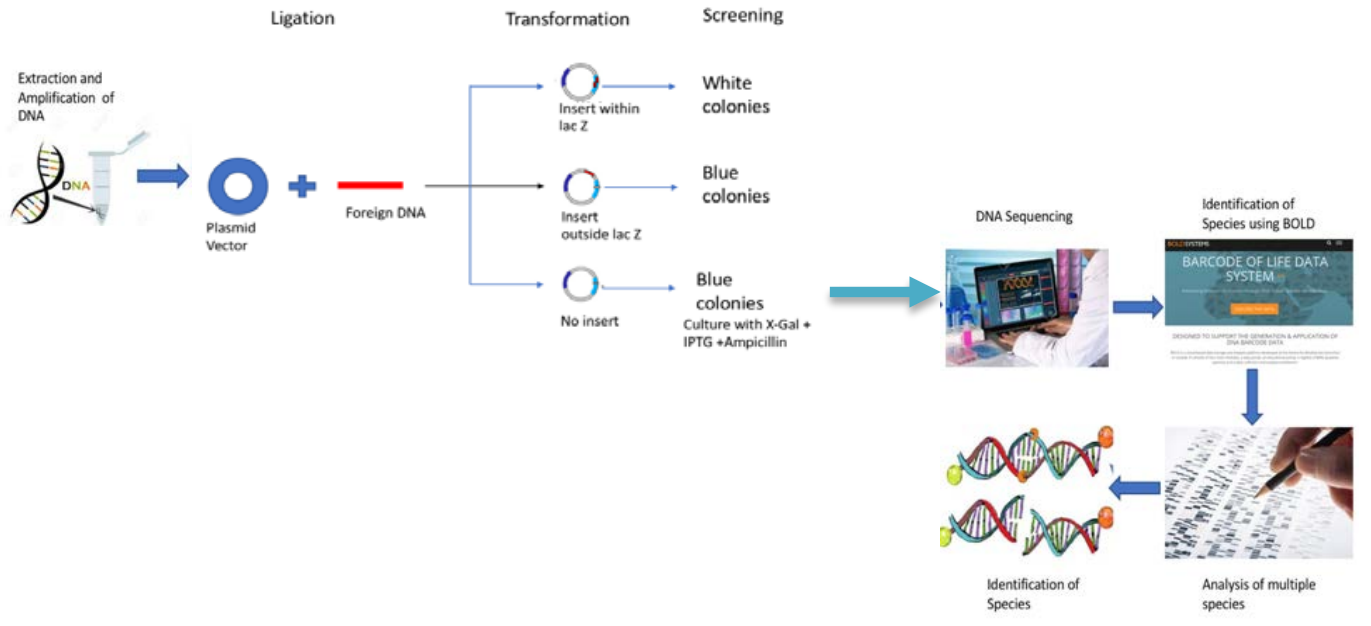

Figure 1: Comparison of (a) DNA Barcoding and (b) PCR cloning for analysis of species mixtures

\subsection{Rationale and Significance}

Species identification is important for regulating proper labeling of food products, including those that are highly processed and/or contain species mixtures. The rationale behind this study is that although various DNA barcoding techniques have been 
established for species identification, no definitive research has been done on the ability of PCR cloning combined with DNA barcoding to identify specific fish in a mixedspecies sample with known amounts of each species. DNA barcoding techniques have been performed on various fish products but can be improved with PCR cloning techniques for the identification of species in fish mixture products.

The overall goal of this study is to determine whether PCR cloning with full and/or mini DNA barcodes can be used to identify species in a processed fish product containing multiple species. The working hypothesis for this aim is that species identification for multi-species food products can be conducted with PCR cloning (GalalKhallaf and others 2016)

The study is significant because it will provide an accurate species identification technique for fish balls and allow for better regulation efforts for specific fish species in fish mixture-based products. The excepted outcome will benefit food regulators and consumers by providing an effective fish mixture species identification technique.

\section{Materials and Methods}

\subsection{Sample collection and preparation}

Fifteen fish ball samples were prepared containing specific weight proportions of Nile tilapia, Pacific cod, and walleye pollock (Table 1). Fillets corresponding to each species were purchased from local grocery stores in Orange County, CA, USA. Prior to use in

this study, the fillets were first authenticated with DNA barcoding (described below) and then stored at $-20{ }^{\circ} \mathrm{C}$ until authentication was complete. Fish balls were prepared using an adapted recipe from China Sichuan Food (https://www.chinasichuanfood.com/how-tomake-fish-balls/). The authenticated fillets from the three species of fish were used to prepare 100-g mixtures at the proportions specified in Table 1. Each fish mixture was 
homogenized with $10 \mathrm{~g}$ ice and $10 \mathrm{ml}$ deionized water in a sterile 12-speed Oster blender (Fort Lauderdale, Florida, USA) for $2 \mathrm{~min}$ at speed 2. Next, $0.3 \mathrm{~g}$ of salt and $0.4 \mathrm{~g}$ of sugar were added and the mixture was blended for 1-2 min at speed 5 . Then, an additional $8 \mathrm{~g}$ of ice and $3 \mathrm{ml}$ deionized water were added and mixed for $2 \mathrm{~min}$ at speed 11. This step was repeated and blended at speed 4 . Finally, $0.4 \mathrm{~g}$ of cornstarch and $5 \mathrm{ml}$ deionized water was added to the mixture and blended for 2 min at speed 8 . The mixture was then rolled into a 100-g fish ball and heated in $80^{\circ} \mathrm{C}$ deionized water for 1-2 min. After heating, the fish ball was cooled, placed in an individually labeled Ziploc freezer bag (Racine, Wisconsin, USA), and stored at $-80{ }^{\circ} \mathrm{C}$ until further analysis.

\subsection{DNA extraction}

DNA extraction was performed in triplicate on each fish ball using the DNeasy Blood and Tissue Kit (Qiagen, Valencia, CA, USA), Spin-Column protocol, with modifications. The amount of starting tissue was increased to $100 \mathrm{mg}$ to better represent the mixed sample. The fish tissue was mixed with $500 \mu \mathrm{l}$ Buffer ATL and $55.6 \mu \mathrm{l}$ proteinase $\mathrm{K}$ in a 2-ml microcentrifuge tube and then incubated at $56{ }^{\circ} \mathrm{C}$ for $2 \mathrm{~h}$ at 300 rpm using a Thermomixer C (Eppendorf, Hamburg, Germany). Next, equal parts (556 $\mu \mathrm{l}$ ) Buffer AL and 95\% ethanol were added to the sample tubes and the tubes were vortexed. A portion (177 $\mu \mathrm{l})$ of each sample was transferred to a DNeasy Mini spin column in a 2 $\mathrm{ml}$ collection tube. Samples were centrifuged ( $8000 \mathrm{x} \mathrm{g}$ ) for $1 \mathrm{~min}$ and the columns were transferred to new collection tubes. The subsequent wash and elution steps were performed as described in Handy et al. (2011b). The extracted DNA was stored at $-80{ }^{\circ} \mathrm{C}$ until PCR and DNA sequencing. A reagent negative blank control was included for each set of DNA extractions. 


\subsection{PCR and DNA sequencing}

All DNA extracts underwent PCR and DNA sequencing using both full (655 bp) and mini-barcoding (226 bp) of the CO1 gene. PCR primers were synthesized by Integrated DNA Technologies (Coralville, IA, USA) and a Master Cycler Nexus Gradient Thermal Cycler (Eppendorf) was used to perform PCR. PCR amplification for mini-barcoding was carried out as described in Pollack et al. (2018) with $16 \mu \mathrm{L}$ of molecular-grade sterile water, $2.5 \mu \mathrm{L}$ 10X buffer, $2.5 \mu \mathrm{L} \mathrm{MgCl}_{2}(50 \mathrm{nM}), 0.5 \mu \mathrm{L}$ dNTPs $(10 \mathrm{mM}), 0.5 \mu \mathrm{L}$ platinum Taq, $0.5 \mu \mathrm{L}$ of $10 \mu \mathrm{M}$ forward primer cocktail, $0.5 \mu \mathrm{L}$ of $10 \mu \mathrm{M}$ reverse primer, and 2.0 $\mu \mathrm{L}$ of template DNA(Pollack and others 2018). The cycling conditions for fish mini-barcoding were: $95^{\circ} \mathrm{C}$ for $5 \mathrm{~min}$; 35 cycles of $94^{\circ} \mathrm{C}$ for $40 \mathrm{~s}, 46^{\circ} \mathrm{C}$ for one min, and $72^{\circ} \mathrm{C}$ for $30 \mathrm{~s}$; and a final extension step at $72^{\circ} \mathrm{C}$ for 5 min (Pollack and others 2018). PCR for the fish full-barcode was carried out as described in Handy et al. (2011a)using 6.25 $\mu \mathrm{L}$ 10\% Trehalose, $2 \mu \mathrm{L}$ of DI water, $1.25 \mu \mathrm{L}$ 10X PCR Buffer, $0.625 \mu \mathrm{L}$ of $\mathrm{MgCl}_{2}$

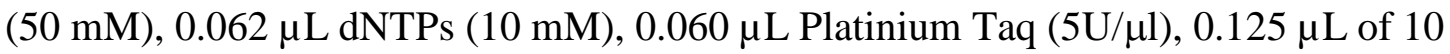
$\mu \mathrm{M}$ forward primer, $0.125 \mu \mathrm{L}$ of $10 \mu \mathrm{M}$ reverse primer, and 1.0 $\mu \mathrm{L}$ of template DNA. The cycling conditions for fish full barcoding were: $94^{\circ} \mathrm{C}$ for $2 \mathrm{~min}$; 35 cycles of $94^{\circ} \mathrm{C}$ for $30 \mathrm{~s}, 55^{\circ} \mathrm{C}$ for $40 \mathrm{~s}$, and $72^{\circ} \mathrm{C}$ for $1 \mathrm{~min}$; and a final extension step at $72^{\circ} \mathrm{C}$ for $10 \mathrm{~min}$ (Handy and others 2011b). PCR product confirmation for full and mini-barcodes was carried out with 2\% agarose E-Gels (Invitrogen, Carlsbad, CA, USA) run on an E-Gel iBase (Invitrogen) for 15 min (Pollack and others 2018). The results were visualized using a FOTO/Analyst Express (Fotodyne, Hartland, WI, USA) and Transilluminator (Fisher Scientific, Waltham, MA, USA) combined with FOTO/Analyst PCImage (version 5.0.0.0, FOTODYNE). Samples with a PCR band correlating to the target region length 
were considered successfully amplified and prepared for DNA sequencing. PCR products were cleaned using ExoSAP-IT (Affymetrix, Santa Clara, CA, USA) following the manufacturer's instructions. Next, bi-directional cycle sequencing was carried out using the M13 primers as described in Handy et al. (2011b). Sequencing purification was performed using a Performa DTR V3 96-well short plate (Edge Bio, Gaithersburg, MD, USA). Samples underwent sequencing using a 3500xl Genetic Analyzer (Thermo Fisher Scientific, Waltham, MA, USA) using POP-7 polymer (Thermo Fisher Scientific).

\subsection{Sequence analysis}

Raw sequence data was assembled and edited using Geneious v.5.4.7 (Biomatters Ldt., Auckland, New Zealand) following steps described in Handy et al. (2011b). Full barcodes were only considered successful if they met the following quality control (QC) parameters: bi-directional sequences with $\geq 500$ bp and $<2 \%$ ambiguities or single reads with $\geq 500$ bp and $\geq 98 \%$ high-quality bases (Handy and others 2011b). Mini-barcodes were analyzed using QC parameters described in Pollack et al. (2018), which call for bidirectional sequences that are $\geq 171$ bp and have $<2 \%$ ambiguities or single reads that are $\geq 171$ bp and have $\geq 98 \%$ high-quality bases. Samples that did not produce an assembled sequence underwent repeat DNA extraction, PCR, and sequencing. PCR amplicons from samples with assembled sequences that did not meet QC parameters were used for PCR cloning, due to the assumption that QC failure was due to the presence of a species mixture. Sequences that passed QC were identified to the species level using the Barcode of Life Database (BOLD) Animal Identification Request Engine (http://www.boldsystems.org/), Species Level Barcode Records. 


\subsection{PCR cloning}

Samples with assembled sequences that did not pass QC sequencing parameters were further analyzed through PCR cloning using the Qiagen PCR cloning Kit (Qiagen). Each PCR product ( $2 \mu \mathrm{l}$ ) was ligated to the commercially prepared Qiagen pDrive A/U cloning vector $(1 \mu \mathrm{l})$ with $2 \mathrm{x}$ buffer $(5 \mu \mathrm{l})$ and nuclease free water $(2 \mu \mathrm{l})$ for $2 \mathrm{~h}$ at $4{ }^{\circ} \mathrm{C}$. Next, the ligations were transformed into E. coli competent cells with the addition of $2 \mu \mathrm{l}$ of ligation-reaction mixture to QIAGEN EZ Competent Cells (Qiagen). This mixture was incubated on ice for $5 \mathrm{~min}$, heated at $42^{\circ} \mathrm{C}$ for $30 \mathrm{~s}$ incubated on ice for $2 \mathrm{~min}$, and then removed from ice. Next, $250 \mu \mathrm{l}$ of Super Optimal Broth with Catabolite repression SOC medium was thoroughly mixed in each tube and $100 \mu \mathrm{l}$ of the sample was plated on Luria Bertani agar containing ampicillin, X-Gal, and Isopropyl B-D-1 thiogalactopyranoside (IPTG). The plates were incubated at $37^{\circ} \mathrm{C}$ overnight. Next, white colonies bearing PCR strand inserts were transferred to fresh Trypticase Soy Broth with $0.6 \%$ Yeast Extract (TSBYE) broth with $100 \mu \mathrm{g} / \mathrm{m}$ of ampicillin for plasmid selection. A plasmid mini-prep was performed on 10 independent plasmid clones for each sample, which served as the template for DNA sequencing. Prior to sequencing, each plasmid clone underwent a restriction digest that included $10 \mu \mathrm{l}$ plasmid, $2.0 \mu \mathrm{l}$ 10x buffer, $0.5 \mu \mathrm{l}$ EcoRI, and $7.5 \mu \mathrm{l}$ $\mathrm{H}_{2} \mathrm{O}$ incubated in a $37^{\circ} \mathrm{C}$ water bath for $2 \mathrm{~h}$. The digested plasmids were then mixed with loading dye (5 $\mu \mathrm{l})$ and $10 \mu \mathrm{l}$ was pipetted to the appropriate wells of a $2 \%$ agarose E-gel to confirm that PCR inserts were still present. If individual cloned isolates did not have PCR inserts, additional clones were selected for a total of 10 PCR bearing clones. Plates with additional white colonies were stored at $4{ }^{\circ} \mathrm{C}$ in case additional clones needed to be selected for analysis. Ten individual plasmid templates were DNA sequenced in the 
forward and reverse direction using T7 and SP6 primers, respectively. The raw sequences were analyzed, and top species matches were identified as described above in the ‘Sequence analysis’ section.

\section{Results and Discussion}

\subsection{Standard Full Barcoding}

As shown in Table 2, full-barcoding enabled identification of at least one species for all 15 fish ball mixtures tested. Sequencing success, defined by the ability to obtain a species identification for a given subsample, for each fish ball ranged from 33.3\% (1 of 3 subsamples identified) to 100\% (3 of 3 subsamples identified). Among the three fish balls that contained a single species, all three subsamples were identified, for a sequencing success rate of $100 \%$ (9 of 9). In regard to the mixed-species samples, the overall sequencing success rate was $75.0 \%$ (27 of 36). Five of the mixed-species samples (nos. 4,

$5,6,7,11$ ) showed $100 \%$ sequencing success; another five mixed samples (nos. 1, 2, 3, 9, 12) had $66.6 \%$ sequencing success; and one mixture (no. 10) had $33.3 \%$ sequencing success (Table 4). Similarly, Galal-Khallaf et al. (2016) reported a low sequencing success rate (45\%) for surimi-based mixed fish products. This low rate may be attributed to multiple species producing peaks in a chromatogram during sequencing (Galimberti and others 2013). In comparison, Pollack et al. (2018) reported a full barcoding success rate of $90 \%$ for single-species fish products processed in a variety of ways.

The average length of successfully sequenced full barcodes was 650 bp with a range of 558-655 bp. The sequence quality for successfully sequenced samples was variable, ranging from $45.5 \%$ to $99.7 \%$, with an average of $77.9 \%$. The average percent ambiguities among the full barcodes was $0.49 \%$, with a range of $0.0-1.9 \%$. In comparing 
single-species samples to mixed-species samples in this study, the single-species samples had a higher average sequence length (654 bp vs. 650 bp), higher average sequence quality (88.0\% vs $77.9 \%$ ), and lower average percent ambiguities ( $0.48 \%$ vs $0.49 \%)$. In comparison, Pollock et al. (2018) had an average barcode length of 652 bp, an average sequence quality of $96.9 \%$, and $0.08 \%$ ambiguities for single-species fish products.

All successfully obtained sequences showed $99.5-100 \%$ genetic similarity to species in BOLD. Each of the single-species fish balls was identified as the correct species using full barcoding. However, the only species detected in all of the mixedspecies samples was Nile tilapia (Table 2), suggesting the occurrence of primer bias. The full barcode primers used in the current study have previously demonstrated the ability to detect Pacific cod and walleye pollock in single-species processed fish products (2013; 2018), similar to the current study. Given that this primer set is known to be effective in identifying single species fish, including pollock and cod, the inability to identify them in mixed-species fish ball samples suggests preferential primer binding to Nile tilapia. Primer bias has previously been reported for DNA barcoding of mixed-fish products using NGS techniques with the cytochrome $b$ gene, in which an overrepresentation of skipjack tuna was identified (Kappel and others 2017). For example, a mixture in this study included 50\% albacore (T. alalunga), 40\% yellowfin tuna (T. albacares), and 10\% skipjack tuna (K. pelamis). After sequencing, it was determined that 50\% was albacore, $30 \%$ of the mixture was skipjack tuna, and $10 \%$ was yellowfin tuna. Primer bias has also been reported to be a problem in other studies involving DNA barcoding, such as DNA metabarcoding research involving macroinvertebrates (Deiner and others 2017; Elbrecht and Leese 2017). Primer bias can lead to a misinterpretation of the species present in a 
sample and could be a concern for regulators and consumers due to the inability to identify certain species in a product.

Table 4. Sequencing results for fish ball samples tested in triplicate with full and miniDNA barcoding. Samples contained varying amounts of Nile tilapia (O. niloticus), Pacific cod (G. macrocephalus), and walleye pollock (T. chalcogramma).

\begin{tabular}{llllll}
\hline $\begin{array}{l}\text { Fish } \\
\text { ball } \\
\text { sample } \\
\text { no. }\end{array}$ & $\begin{array}{l}\text { \%Tilapia/cod/ } \\
\text { pollock } \\
\text { (wt/wt/wt) }\end{array}$ & $\begin{array}{l}\text { Full barcoding } \\
\begin{array}{l}\text { No. of } \\
\text { successful } \\
\text { sequences }^{\mathrm{a}}\end{array}\end{array}$ & $\begin{array}{l}\text { Top species } \\
\text { match }\end{array}$ & $\begin{array}{l}\text { No. of } \\
\text { successful } \\
\text { sequences }^{\mathrm{a}}\end{array}$ & $\begin{array}{l}\text { Top } \\
\text { species } \\
\text { match }\end{array}$ \\
\hline 1 & $98 / 1 / 1$ & $2 / 3$ & Nile tilapia & $3 / 3$ & Nile tilapia \\
2 & $1 / 98 / 1$ & $2 / 3$ & Nile tilapia & $0 / 3$ & N/A \\
3 & $1 / 1 / 98$ & $2 / 3$ & Nile tilapia & $1 / 3$ & Nile tilapia \\
4 & $90 / 5 / 5$ & $3 / 3$ & Nile tilapia & $2 / 3$ & Nile tilapia \\
5 & $5 / 90 / 5$ & $3 / 3$ & Nile tilapia & $0 / 3$ & N/A \\
6 & $5 / 5 / 90$ & $3 / 3$ & Nile tilapia & $3 / 3$ & Nile tilapia \\
7 & $80 / 10 / 10$ & $3 / 3$ & Nile tilapia & $3 / 3$ & Nile tilapia \\
8 & $10 / 80 / 10$ & $1 / 3$ & Nile tilapia & $0 / 3$ & N/A \\
9 & $10 / 10 / 80$ & $2 / 3$ & Nile tilapia & $0 / 3$ & N/A \\
10 & $50 / 25 / 25$ & $1 / 3$ & Nile tilapia & $0 / 3$ & N/A \\
11 & $25 / 50 / 25$ & $3 / 3$ & Nile tilapia & $2 / 3$ & Nile tilapia \\
12 & $25 / 25 / 50$ & $2 / 3$ & Nile tilapia & $0 / 3$ & N/A \\
13 & $100 / 0 / 0$ & $3 / 3$ & Nile tilapia & $3 / 3$ & Nile tilapia \\
14 & $0 / 100 / 0$ & $3 / 3$ & Pacific cod & $3 / 3$ & Pacific cod \\
15 & $0 / 0 / 100$ & $3 / 3$ & Walleye & $3 / 3$ & Walleye \\
& & & pollock & & pollock \\
\hline
\end{tabular}

aBased on quality control parameters described in Handy et al. (2011a) for full barcodes and Pollack et al. (2018)for mini-barcodes

\subsection{PCR Cloning combined with Full Barcoding}

The nine fish ball subsamples that were not successfully sequenced with standard full barcoding were partially identified through PCR cloning and DNA sequencing (Table 3). Out of the 90 clones sequenced, 55 (61\%) had sequences that passed quality control parameters according to Handy et al. (2011b). One of the subsamples (no. 8-B), which included $80 \%$ cod, $10 \%$ pollock, and $10 \%$ tilapia, had $100 \%$ sequencing success among the 10 clones. On the other hand, five of the subsamples (nos. 3-A, 8-A,10-A,10-B,12-A) 
had $\leq 50 \%$ sequencing success rate. The subsamples with the highest percentage of a single fish (e.g., 98/1/1\%) had the highest sequencing success rate, at 70\%. Subsamples with $80 \%$ of a single fish (e.g., 10/80/10\%) had an average success rate of $67 \%$ and subsamples in which no fish was present at $>50 \%$ (e.g., 50/25/25\%) had the lowest success rate, at 43\% (Table 3). Overall, the SP6 primer showed greater sequencing success (35/45 clones) compared to the T7 primer (10/45 clones) for the fish ball mixtures.

As shown in Table 3, Nile tilapia was identified in all nine subsamples and Pacific cod was identified in six of the subsamples. However, walleye pollock was not identified in any of the subsamples. All species-level identifications showed high genetic similarity ( $\geq 99.6 \%$ ) to sequences in BOLD. Overall, the combination of standard full barcoding and PCR cloning enabled identification of Nile tilapia in all 12 mixed-species fish balls and identification of Pacific cod in 6 of 12 (50\%) of mixed-species fish balls.

In analyzing the ratios of each species in fish mixtures, no correlation was found between the percentage of each fish in a mixture and the percentage of identifications for that species among the ten clones sequenced. For example, subsample 8-B contained 80\% Pacific cod, $10 \%$ walleye pollock., and $10 \%$ Nile tilapia; however, the sequencing results showed Nile tilapia identifications for $80 \%$ of the 10 clones, and Pacific cod identifications for $20 \%$ of the clones. This discrepancy is likely a continued effect of the primer bias observed with standard DNA barcoding combined with the low number of clones sequenced per subsample. While it is possible that sequencing a higher number of clones may result in a more accurate representation of the species present, the matter of primer bias would also need to be reconciled. 
The average full-barcode length for successfully sequenced clones was 639 bp (range: 547-655 bp), which was lower than that reported for standard full barcoding (650 bp). The average sequence quality was $95.0 \%$ (range: 43.6-100\%), which was higher than standard full barcoding (77.9\%). The average percent ambiguities among the successfully sequenced clones was $0.12 \%$, with a range of $0-1.9 \%$, which was lower than standard full barcoding (0.49\%).

Table 5. Sequencing results for fish ball subsamples that underwent PCR cloning and full DNA barcoding after failing standard full barcoding. Ten clones were sequenced for each PCR product that failed standard barcoding.

\begin{tabular}{|c|c|c|c|c|c|}
\hline \multirow{2}{*}{$\begin{array}{l}\text { Fish ball } \\
\text { subsamp } \\
\text { le no. }\end{array}$} & \multirow{2}{*}{$\begin{array}{l}\text { \%Tilapia/cod } \\
\text { / pollock } \\
\text { (wt/wt/wt) }\end{array}$} & \multirow{2}{*}{$\begin{array}{l}\text { No. of } \\
\text { successful } \\
\text { sequenced } \\
\text { clones }^{\text {a }}\end{array}$} & \multicolumn{3}{|c|}{ No. of clones identified as each species } \\
\hline & & & $\begin{array}{l}\text { Nile } \\
\text { tilapia } \\
\text { (O. } \\
\text { niloticus) }\end{array}$ & $\begin{array}{l}\text { Pacific cod } \\
\text { (G. } \\
\text { macrocephalus) }\end{array}$ & $\begin{array}{l}\text { Walleye pollock } \\
\text { (T. } \\
\text { chalcogramma) }\end{array}$ \\
\hline 1-A & $98 / 1 / 1$ & $9 / 10$ & 8 & 1 & 0 \\
\hline $2-\mathrm{A}$ & $1 / 98 / 1$ & $7 / 10$ & 7 & 0 & 0 \\
\hline 3-A & $1 / 1 / 98$ & $5 / 10$ & 4 & 1 & 0 \\
\hline 8-A & $10 / 80 / 10$ & $4 / 10$ & 4 & 0 & 0 \\
\hline 8-B & $10 / 80 / 10$ & $10 / 10$ & 8 & 2 & 0 \\
\hline $9-\mathrm{C}$ & $10 / 10 / 80$ & $6 / 10$ & 1 & 5 & 0 \\
\hline $10-\mathrm{A}$ & $50 / 25 / 25$ & $5 / 10$ & 1 & 4 & 0 \\
\hline $10-B$ & $50 / 25 / 25$ & $4 / 10$ & 4 & 0 & 0 \\
\hline 12-B & $25 / 25 / 50$ & $4 / 10$ & 2 & 2 & 0 \\
\hline
\end{tabular}

${ }^{a}$ Based on quality control parameters described in Handy et al.(2011b)

\subsection{Standard Mini-Barcoding}

Standard mini-barcoding enabled identification of at least one species in only 9 of the 15 fish ball samples tested (Table 2). Similar to full barcoding, all three single-species samples showed $100 \%$ sequencing success and were identified as the expected species. However, samples with multiple fish species showed a relatively low overall sequencing success rate of $38.9 \%$ (14 of 36 ) as compared to $75.0 \%$ for full barcoding. Among the mixed-species samples, three (nos. 1, 6, 7) had a sequencing success rate of $100 \%$; two 
(nos. 4,11 ) had a rate of $66.6 \%$; and one (no. 3) had a success rate of 33.3\%. The identification of a fewer number of samples with mini-barcoding as compared to full barcoding may actually be advantageous when working with mixed-species products. This is because sequencing failure is an indication that there may be more than one species in the product, among other things. A sample that fails to be identified with standard barcoding techniques could be flagged for additional analysis while it is likely that additional testing would not be carried out on a sample with a single species identified.

The average mini-barcode sequence length for successfully sequenced samples was 224 bp with a range of 216-226 bp. Despite the presence of multiple species in some samples, the average sequence quality for successfully sequenced mini-barcodes was relatively high, at 95.9\% (range: $83.2 \%-99.1 \%$ ) and the average percent ambiguities was low, at $0.23 \%$ (range: $0.0-1.8 \%$ ). Consistent with the results of full barcoding, the singlespecies samples had a higher average sequence length (226 bp) compared to mixedspecies samples (224 bp), lower average sequence quality (85.6\% vs. 95.9\%), and a lower average percent ambiguity ( $0.16 \%$ vs. $0.23 \%)$. Similar to the results for single-species samples in the current study, Pollack et al. (2018) reported an average sequencing length of $226 \mathrm{bp}$, sequencing quality of $96.9 \%$, and percent ambiguities of $0.02 \%$ for minibarcodes from single-species fish samples.

All nine fish ball samples that were successfully sequenced were identified to the species level in BOLD, with $100 \%$ genetic similarity. Fish ball samples containing only a single species were identified as containing the expected species. However, similar to the results of full barcoding, all six fish ball samples with mixed species were identified only 
as containing Nile tilapia. The same forward primer was used in this study for both full and mini-barcoding, which may explain the continued occurrence of primer bias. While the SH-E mini barcode primers were used in this study due to recent success with single fish species analysis conducted by Pollack et al (2018), the use of other mini-barcode primers with different primer sequences, such as SH-D , should also be examined (Shokralla and others 2015).

\subsection{PCR Cloning combined with Mini-Barcoding}

Among the 22 mini-barcode subsamples that did not pass traditional sequencing, 21 were partially identified with PCR cloning and DNA sequencing (Table 4). Out of the 220 clones tested, 111 (50.5\%) passed quality control parameters according to Pollack et al. (2018). More than half of the subsamples had $\geq 50 \%$ sequencing success. As expected, the subsamples in which all three species of fish were present at $\geq 25 \%$ (e.g., 50/25/25\%) had the highest average success rate (77\%) and the subsamples with fish at levels as low as $1 \%$ (e.g., 98/1/1\%) had the lowest success rate (36\%).

Mini-barcode cloning had a higher sequencing quality (99.7\%) and lower \% ambiguities (0.01\%) compared to full barcoding cloning (95.0\% and $0.12 \%$, respectively). As well, the percent of clones that passed for full barcode cloning was higher (61\%) compared to mini-barcode cloning (50.5\%). In analyzing the ratios of each species in fish mixtures, no correlation was found between the percentage of each fish in a mixture and the percentage of identifications for that species among the ten clones sequenced. For example, mixture 10C, which consisted of 50\% walleye pollock, $25 \%$ Nile tilapia, and 25\% Pacific cod, was sequenced to be 78\% Nile tilapia, 22\% Pacific cod, and $0 \%$ walleye pollock. 
The average mini-barcode sequence lengths for successfully sequenced clones was 225 bp (range: 225-226 bp). The average sequence quality for successfully sequenced clones was 99.7\% (range: 93.4-100\%) and the average percent ambiguities was $0.01 \%$ (range: $0-1 \%$ ). The average sequence length and quality for cloned minibarcode sequences were higher compared to standard mini-barcoding (224 bp and 95.9\%, respectively). On the other hand, the cloned mini-barcode sequences had a lower percent ambiguity (0.01\%) compared to standard mini-barcoding $(0.23 \%)$.

Similar to the results for PCR cloning of full barcodes, both Pacific cod and Nile tilapia were identified in the subsamples. Nile tilapia was detected in the highest number of subsamples ( $\mathrm{n}=18)$, while Pacific cod was detected in 16 subsamples (Table 4). Both species showed high genetic similarity (99.1-100\%) to sequences in BOLD. However, consistent with the other results of this study, walleye pollock was not identified in any of the subsamples. Overall, the combination of standard mini-barcoding and PCR cloning enabled identification of Nile tilapia in all 12 mixed-species fish balls and identification of Pacific cod in 9 of 12 (75\%) of mixed-species fish balls. 
Table 6. Sequencing results for fish ball samples that underwent PCR cloning and minibarcoding after failing standard mini-barcoding. Ten clones were sequenced for each PCR product that failed standard barcoding.

\begin{tabular}{|c|c|c|c|c|c|}
\hline \multirow{2}{*}{$\begin{array}{l}\text { Fish } \\
\text { ball } \\
\text { subsam } \\
\text { ple no. }\end{array}$} & \multirow{2}{*}{$\begin{array}{l}\text { \% Tilapia/ } \\
\text { cod/pollock } \\
\text { (wt/wt/wt) }\end{array}$} & \multirow{2}{*}{$\begin{array}{l}\text { No. of } \\
\text { successful } \\
\text { sequenced } \\
\text { clones }^{\text {a }}\end{array}$} & \multicolumn{3}{|c|}{ No. of clones identified as each species } \\
\hline & & & $\begin{array}{l}\text { Nile } \\
\text { tilapia } \\
\text { (O. } \\
\text { niloticus) }\end{array}$ & $\begin{array}{l}\text { Pacific cod } \\
\text { (G. } \\
\text { microcephalus) }\end{array}$ & $\begin{array}{l}\text { Walleye pollock } \\
(T . \\
\text { chalcogramma) }\end{array}$ \\
\hline $2-\mathrm{A}$ & $1 / 98 / 1$ & $3 / 10$ & 0 & 3 & 0 \\
\hline $2-\mathrm{B}$ & $1 / 98 / 1$ & $0 / 10$ & 0 & 0 & 0 \\
\hline $2-\mathrm{C}$ & $1 / 98 / 1$ & $6 / 10$ & 6 & 0 & 0 \\
\hline 3-B & $1 / 1 / 98$ & $4 / 10$ & 3 & 1 & 0 \\
\hline $3-\mathrm{C}$ & $1 / 1 / 98$ & $5 / 10$ & 5 & 0 & 0 \\
\hline $4-\mathrm{C}$ & $90 / 5 / 5$ & $5 / 10$ & 4 & 1 & 0 \\
\hline 5-A & $5 / 90 / 5$ & $1 / 10$ & 1 & 0 & 0 \\
\hline $5-B$ & $5 / 90 / 5$ & $4 / 10$ & 1 & 3 & 0 \\
\hline $5-C$ & $5 / 90 / 5$ & $7 / 10$ & 2 & 5 & 0 \\
\hline 8-A & 10/80/10 & $3 / 10$ & 3 & 0 & 0 \\
\hline 8-B & $10 / 80 / 10$ & $5 / 10$ & 3 & 2 & 0 \\
\hline 8-C & $10 / 80 / 10$ & $1 / 10$ & 0 & 1 & 0 \\
\hline 9-A & $10 / 10 / 80$ & $3 / 10$ & 0 & 3 & 0 \\
\hline 9-B & $10 / 10 / 80$ & $3 / 10$ & 2 & 1 & 0 \\
\hline 9-C & $10 / 10 / 80$ & $7 / 10$ & 7 & 0 & 0 \\
\hline $10-A$ & $50 / 25 / 25$ & $8 / 10$ & 5 & 3 & 0 \\
\hline $10-B$ & $50 / 25 / 25$ & $7 / 10$ & 4 & 3 & 0 \\
\hline $10-C$ & $50 / 25 / 25$ & $9 / 10$ & 6 & 3 & 0 \\
\hline 11-B & $25 / 50 / 25$ & $9 / 10$ & 7 & 2 & 0 \\
\hline $12-A$ & $25 / 25 / 50$ & $7 / 10$ & 5 & 2 & 0 \\
\hline $12-B$ & $25 / 25 / 50$ & $8 / 10$ & 2 & 6 & 0 \\
\hline $12-C$ & $25 / 25 / 50$ & $6 / 10$ & 0 & 6 & 0 \\
\hline
\end{tabular}

${ }^{\text {a} B a s e d ~ o n ~ q u a l i t y ~ c o n t r o l ~ p a r a m e t e r s ~ d e s c r i b e d ~ i n ~ P o l l o c k ~ e t ~ a l . ~(2018) ~}$

\section{Conclusions}

Overall, this study revealed the ability of PCR cloning combined with DNA barcoding to identify multiple fish in a mixed-species sample; however, this technique was unable to identify all fish species present. While only one species (Nile tilapia) was identified in mixed-species fish balls using standard DNA barcoding techniques, PCR cloning of the DNA mini-barcode enabled the identification of a second species (Pacific 
cod) in $75 \%$ of fish balls. However, none of the techniques was able to identify the presence of walleye pollock in any of the fish balls. Furthermore, PCR cloning was unable to identify the composition of specific ratios of each fish in the mixture. Primer bias was considered a significant issue in this study, and further research is needed to determine whether alternative primer sets would enable detection of a greater range of fish species. The use of high-level techniques, such as next-generation sequencing, should also be examined for potential use in testing mixed-species samples for regulatory purposes. 


\section{References}

Angel Pardo M, Jimenez E, Vidarsson JR, Olafsson K, Olafsdottir G, Danielsdottir AK, Perez-Villareal B. 2018. DNA barcoding revealing mislabeling of seafood in European mass caterings. Food Control 92:7-16.

Armani A, Guardone L, La Castellana R, Gianfaldoni D, Guidi A, Castigliego L. 2015. DNA barcoding reveals commercial and health issues sold on the Italian market in ethnic seafood. Food Control 55:206-14.

Boran M, Kose S. 2007. Storage Properties of Three Types of Fried whiting Balls at Refrigerated Temperatures. Turkish Journal of Fisheries and Aquatic Sciences $7: 65-70$.

Bruni I, Galimberti A, Caridi L, Scaccabarozzi D, Mattia Fd, Casiraghi M, Labra M. 2015. A DNA barcoding approach to identify plant species in multiflower honey. Food Chemistry 170:308-15.

Carvalho DC, Guedes D, Gloria Trindade Md, Sartori Coelho RM, de Lima Araujo PH. 2017a. Nationwide Brazilian governmental forensic programme reveals seafood mislabelling trends and rates using DNA barcoding. Fisheries Research 191:30-5.

Carvalho DC, Palhares RM, Drummond MG, Gadanho M. 2017b. Food metagenomics: Next generation sequencing identifies species mixtures and mislabeling within highly processed cod products. Food Control 80:183-6.

Cawthorn D-M, Steinman HA, Witthuhn RC. 2011. Comparative study of different methods for the extraction of DNA from fish species commercially available in South Africa. Food Control 22(2):231-44. 
Cline E. 2012. Marketplace substitution of Atlantic salmon for Pacific salmon in Washington State detected by DNA barcoding. Food Research International 45(1):388-93.

De Battisti C, Marciano S, Magnabosco C, Busato S, Arcangeli G, Cattoli G. 2014. Pyrosequencing as a Tool for Rapid Fish Species Identification and Commercial Fraud Detection. Journal of Agricultural and Food Chemistry 62(1):198-205. Deagle BE, Tollit DJ, Jarman SN, Hindell MA, Trites AW, Gales NJ. 2005. Molecular scatology as a tool to study diet: analysis of prey DNA in scats from captive Steller sea lions. Molecular Ecology 14(6):1831-42.

Deiner K, Bik HM, Machler E, Seymour M, Lacoursiere-Roussel A, Altermatt F, Creer S, Bista I, Lodge DM, de Vere N, Pfrender ME, Bernatchez L. 2017. Environmental DNA metabarcoding: Transforming how we survey animal and plant communities. Molecular Ecology 26(21):5872-95.

Di Pinto A, Di Pinto P, Terio V, Bozzo G, Bonerba E, Ceci E, Tantillo G. 2013. DNA barcoding for detecting market substitution in salted cod fillets and battered cod chunks. Food Chemistry 141(3):1757-62.

Donne-Gousse C, Laudet V, Hanni C. 2005. Method for determining the existence of animal or vegetable mixtures in organic substances. (10/480587).

Elbrecht V, Leese F. 2017. Validation and Development of COI Metabarcoding Primers for Freshwater Macroinvertebrate Bioassessment. Frontiers in Environmental Science 5:1-11. 
FAO. 2018. The State of World Fisheries and Aquaculture 2018. Contributing to food security and nutrition for all. Rome, Italy: Food and Agriculture Organization of the United Nations.

Fox M, Mitchell M, Dean M, Elliott C, Campbell K. 2018. The seafood supply chain from a fraudulent perspective. Food Security 10(4):939-63.

Galal-Khallaf A, Ardura A, Borrell YJ, Garcia-Vazquez E. 2016. Towards more sustainable surimi? PCR-cloning approach for DNA barcoding reveals the use of species of low trophic level and aquaculture in Asian surimi. Food Control 61:62-

9.

Galal-Khallaf A, Ardura A, Mohammed-Geba K, Borrell YJ, Garcia-Vazquez E. 2014. DNA barcoding reveals a high level of mislabeling in Egyptian fish fillets. Food Control 46:441-5.

Galimberti A, De Mattia F, Losa A, Bruni I, Federici S, Casiraghi M, Martellos S, Labra M. 2013. DNA barcoding as a new tool for food traceability. Food Research International 50(1):55-63.

Giusti A, Armani A, Sotelo CG. 2017. Advances in the analysis of complex food matrices: Species identification in surimi-based products using Next Generation Sequencing technologies. Plos One 12(10).

Handy SM, Deeds JR, Ivanova NV, Hebert PDN, Hanner RH, Ormos A. 2011a. Single Laboratory Validated Method for DNA-Barcoding for the Species Identification of Fish for FDA Regulatory Compliance.

Handy SM, Deeds JR, Ivanova NV, Hebert PDN, Hanner RH, Ormos A, Weigt LA, Moore MM, Yancy HF. 2011b. A Single-Laboratory Validated Method for the 
Generation of DNA Barcodes for the Identification of Fish for Regulatory Compliance. Journal of Aoac International 94(1):201-10.

Hellberg RS, Kawalek MD, Van KT, Shen Y, Williams-Hill DM. 2014. Comparison of DNA Extraction and PCR Setup Methods for Use in High-Throughput DNA Barcoding of Fish Species. Food Analytical Methods 7(10):1950-9.

Ivanova NV, Zemlak TS, Hanner RH, Hebert PDN. 2007. Universal primer cocktails for fish DNA barcoding. Molecular Ecology Notes 7(4):544-8.

Kappel K, Haase I, Kaeppel C, Sotelo CG, Schroeder U. 2017. Species identification in mixed tuna samples with next-generation sequencing targeting two short cytochrome b gene fragments. Food Chemistry 234:212-9.

Khaksar R, Carlson T, Schaffner DW, Ghorashi M, Best D, Jandhyala S, Traverso J, Amini A. 2015. Unmasking seafood mislabeling in U.S. markets: DNA barcoding as a unique technology for food authentication and quality control. Food Control $56: 71-76$.

Lago FC, Vieites JM, Espineira M. 2013. Authentication of gadoids from highly processed products susceptible to include species mixtures by means of DNA sequencing methods. European Food Research and Technology 236(1):171-80.

Liu L, Li YH, Li SL, Hu N, He YM, Pong R, Lin DN, Lu LH, Law M. 2012. Comparison of Next-Generation Sequencing Systems. Journal of Biomedicine and Biotechnology 2012:Article ID 251364.

Morrissey MT, Guenneugues P. 2000. Surimi and surimi seafood. 
Murray DC, Bunce M, Cannell BL, Oliver R, Houston J, White NE, Barrero RA, Bellgard MI, Haile J. 2011. DNA-Based Faecal Dietary Analysis: A Comparison of qPCR and High Throughput Sequencing Approaches. Plos One 6(10).

IUCN Red List. International Union for Conservation of Nature and Natural Resources; 2017.

Ninan G, Bindu J, Joseph J. 2010. Frozen storage studies of value-added mince-based products from Tilapia (Oreochromis Mossambicus, Peters 1852). Journal of Food Processing and Preservation 34:255-71.

NOC. 2016. National ocean Council's committee on illegal, unreported and unregulated (IUU) fishing and seafood fraud (NOC committee). Seafood Fraud Frequently Asked Questions.

Park JY, Lee SY, An CM, Kang J-H, Kim J-H, Chai JC, Chen J, Kang JS, Ahn JJ, Lee YS, Hwang SY. 2012. Comparative study between Next Generation Sequencing Technique and identification of microarray for Species Identification within blended food products. Biochip Journal 6(4):354-61.

Pollack SJ, Kawalek MD, Williams-Hill DM, Hellberg RS. 2018. Evaluation of DNA barcoding methodologies for the identification of fish species in cooked products. Food Control 84:297-304.

Qiagen. 2015. Qiagen PCR Cloning Kit.

Rondon MR, August PR, Bettermann AD, Brady SF, Grossman TH, Liles MR, Loiacono KA, Lynch BA, MacNeil IA, Minor C, Tiong CL, Gilman M, Osburne MS, Clardy J, Handelsman J, Goodman RM. 2000. Cloning the soil metagenome: a 
strategy for accessing the genetic and functional diversity of uncultured microorganisms. Applied and Environmental Microbiology 66(6):2541-7.

Shokralla S, Gibson JF, Nikbakht H, Janzen DH, Hallwachs W, Hajibabaei M. 2014. Next-generation DNA barcoding: using next-generation sequencing to enhance and accelerate DNA barcode capture from single specimens. Molecular Ecology Resources 14(5):892-901.

Shokralla S, Hellberg RS, Handy SM, King I, Hajibabaei M. 2015. A DNA MiniBarcoding System for Authentication of Processed Fish Products. Scientific Reports 5.

Tee E-T, Siow L-F. 2014. Physical and Sensory Properties of Frozen Spanish Mackerel (Scomberomorus guttatus) Fish Balls Added with Cryoprotectants. Food and Bioprocess Technology 7(12):3442-54.

Teletchea F, Maudet C, Hanni C. 2005. Food and forensic molecular identification: update and challenges. Trends in Biotechnology 23(7):359-66.

Thomas T, Gilbert J, Meyer F. 2012. Metagenomics - a guide from sampling to data analysis. Microbial Informatics and Experimentation 2:3.

van Geel B, Fisher DC, Rountrey AN, van Arkel J, Duivenvoorden JF, Nieman AM, van Reenen GBA, Tikhonov AN, Buigues B, Gravendeel B. 2011. Palaeoenvironmental and dietary analysis of intestinal contents of a mammoth calf (Yamal Peninsula, northwest Siberia). Quaternary Science Reviews 30(2728):3935-46. 